\title{
The Engagement of Digital Art with Contemporary Art
}

\author{
Bruce Wands \\ Chair Emeritus \\ MFA Computer Art \\ School of Visual Arts \\ 209 E. 23 St., New York \\ NY 10010, USA \\ www.brucewands.com \\ bwands@sva.edu
}

\begin{abstract}
Digital art is increasingly becoming engaged with contemporary art. Artists began using programming and technology to create art in the 1950s and 1960s and the revolutionary advances in digital technology have spawned new approaches to making art. Originally viewed as outsider art, digital art gained international recognition in the late 1960s and again at the turn of the century. Traditional art institutions were not as quick to embrace this creative use of technology as artists did. In the 1970s, several international organizations were created to support this art form and remain active today. Exhibitions during this period were both juried and curated. During the 1970s and $1980 \mathrm{~s}$, there were very few digital art curators. The change occurred during the late 1990s when museums began to take notice of and exhibit digital art. The Internet has enabled artist, scholar and art institutional websites and the establishment of extensive archives of this art form. This online presence is contributing to the integration of digital art with contemporary art. Publishers have also followed suit and there is now a good selection of books on the theory, history and practice of digital art, led by the MIT Press, Thames \& Hudson, and others. As digital art continues to merge with contemporary art, the division between the two will continue to lessen. However, what is important is to rectify the art historical record to give digital art the rightful place it has earned in the contemporary art landscape.
\end{abstract}

\section{INTRODUCTION}

Digital art is now becoming a vital component of contemporary art. Long seen as outsider art, early digital art was never fully embraced by the traditional art establishment. The roots of the art form trace back to the 1950s with analogue electronic patterns photographed from an oscilloscope by Ben Laposky named Oscillons, $\mathrm{He}$ is often pointed to as setting the stage for digital imaging. What he ushered in was the advent of mathematically inspired imagery. In terms of what has been credited as the first gallery exposure of digital art, we can look at two exhibitions in 1965: Computer Generated Pictures, Bella Julesz and A. Michael Noll, Howard Wise Gallery, New York City and Frieder Nake and Georg Nees with their exhibition, Generative Computergraphik, at the Galerie Wendelin Niedlich in Stuttgart. These exhibitions broke the ground for digital art and generated a lot of curiosity among those interested in new forms of art. The next year saw the establishment of Experiments in Art and
Technology, known as EAT, and Nine Evenings: Theater and Engineering at the Park Avenue Armory, New York City. EAT was founded by engineers Billy Klüver and Fred Waldhauer and artists Robert Rauschenberg and Robert Whitman.

Interest in this new form of creative expression continued to grow and 1968 became a landmark year for digital art. Two major exhibitions were held in London and New York City. Cybernetic Serendipity was held at the Institute of Contemporary Arts (ICA) in London and curated by Jasia Reichardt. This exhibition explored the relationship between technology and creativity. It was divided into three sections:

1) Computer-generated graphics, computer animation, music and poems/text;

2) cybernetic devices as works of art, robotic installations and painting machines; and

3) machines that addressed the history of cybernetics. 
As such, the curator was interested in presenting new forms of art making using various technologies. The Machine as Seen at the End of the Mechanical Age at the Museum of Modern Art, New York City explored the relationship that artists had with machines from a variety of perspectives, and was not an exhibition of digital art, per se.

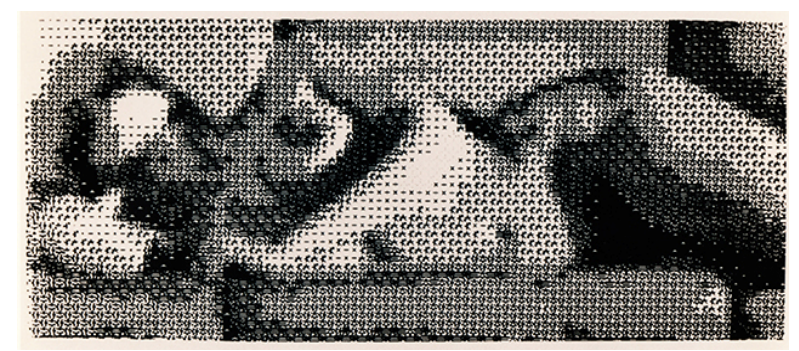

Figure 1: Leon Harmon and Ken Knowlton, Study in Perception, 1966, Computer-generated print, $5 \times 12 \mathrm{ft}$., This image appeared in the Museum of Modern Art exhibition, courtesy of Bruce Wands, Art of the Digital Age, 2006.

This year also saw the establishment of Leonardo, Journal for the International Society for the Arts, Sciences and Technology, by Frank Malina and published by the MIT Press. Leonardo was brought about by his interest in developing crossdisciplinary dialog between artists, scientists and technologists. It remains one of the most important journals of its kind and the entire archive is now available on the Internet. The Computer Arts Society was also established in London in 1968. So, in one way, this was the year when digital art and contemporary art partnered for the first time. While there was an early infatuation with this new form of creative expression, the 1970s through to the 1990s was a time when the creative software and technology was developing to enable and expand the opportunities for creative selfexpression. The World Wide Web came along in 1989 and eventually allowed for websites, images, sound and video to be easily accessed worldwide. While this was happening, the traditional art establishment was still not giving digital art the attention it deserved and since it did not fit into the "painting, drawing and sculpture" categories, curators and art historians did not know what to do with it.

There is a lot of speculation as to why. Some people felt that digital art was still too new to be recognized by museums and galleries. While there were not a lot of artists doing this type of work at the time, there were also art historical and archival issues. Video art was also in its infancy at that time and was suffering from the same problems. However, video was a much more accessible medium, making the acceptance and display of it easier. This contrasts with digital art, which was reliant on the development of visual and interactive computing advances. Early computers used nonarchival paper prints and film as output, as well as custom built and programmed installations. As technology advanced, many of the early works became obsolete due to difficulties in maintaining the hardware and software. Taking a leap forward to the present time, many of the problems with early digital art have been solved and contemporary artists are not looking at digital art as something different, but as a useful tool to incorporate into their art practice.

Archival issues have mostly been solved, largely due to the advances required in the development of digital photography for archival prints and the refinement and stabilizing of digital art software. Interactive media also has a new set of tools ranging from programming languages like Processing and MaxMSP, motion sensing devices and software like Microsoft Kinect, to new advances in gaming, Artificial Intelligence, Augmented and Virtual Reality. One technology that shows huge promise is Google Cardboard (https://vr.google.com/cardboard/) and smartphone apps that allow Virtual Reality to be experienced with inexpensive hardware and also be connected to the Internet.

\section{DIGITAL ART ORGANISATIONS}

One of the ways that digital artists overcame the limitations of exhibiting in museums and galleries was to create organisations that were dedicated to this new form of creative expression. The 1980s saw the establishment of several groups which are still in existence today and have advanced with the times to support research centres, galleries, screening facilities, artist residencies, and some have developed online archives of creative work, videos and documentation of artist talks, panel discussions and symposia. Below is a brief description of some of the better-known organisations and is far from comprehensive.

\section{Ars Electronica}

One of the first to come into existence was Ars Electronica, established in 1979 in Linz, Austria. It was originally a festival and renamed itself Prix Ars Electronica in 1987. In 1996 the Ars Electronica Center and Futurelab were created to form a permanent location for the activities of Ars Electronica and to expand it in a global manner. All these elements are part of the four current areas of focus: the centre, festival, Prix Ars Electronica competition and the Futurelab. This organisation provides a permanent physical as well as online archive, residencies, a museum and other means of supporting and exhibiting new media art. 


\section{SIGGRAPH}

SIGGRAPH is an international professional association that focuses on computing and is a subset of the Association of Computing Machinery (ACM). Founded in 1947, the ACM was formed to promote computing in all its forms. ACM SIGGRAPH is the Special Interest Group in GRAPHics and was founded in 1969. It is a collection of software engineers, technologists, artists and others interested in computer graphics and interactive techniques. This group started the ACM SIGGRAPH Art Gallery in 1981 and has held these exhibitions ever since. The ACM Digital Arts Community was formed in 2003. This is an international group of artists who are connected through their website. There are approximately 1,200 digital artist members. The website has useful information, deadlines, online exhibitions and keeps the community of these artists connected.

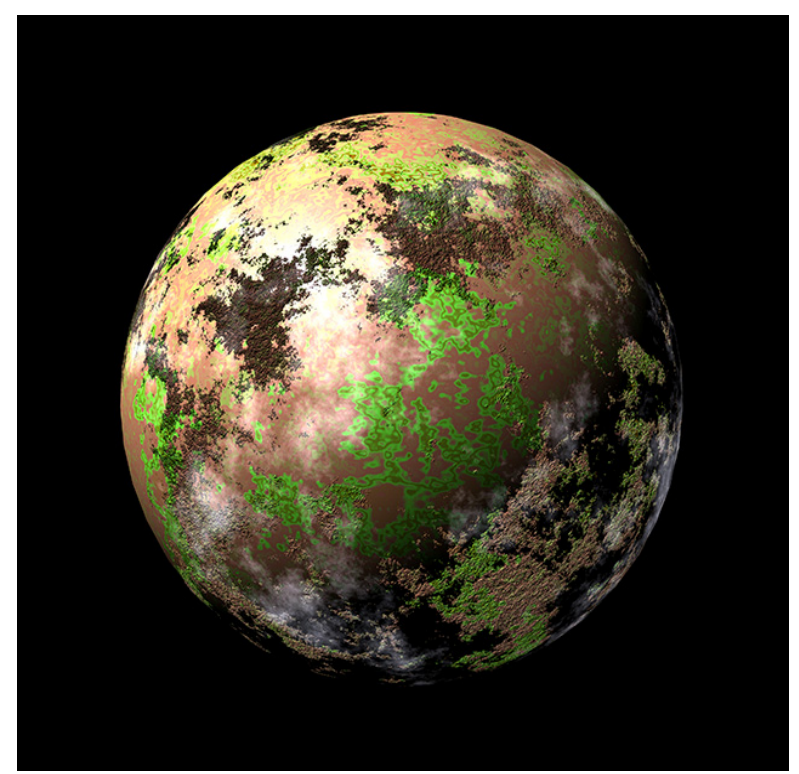

Figure 2: Bruce Wands, The Earth is Art, 2000, digital print, $24 \times 24$ inches. This image was included in the 2003 SIGGRAPH Art Gallery.

\section{V2_ Center for the Unstable Media}

In 1981, the V2_ Center for the Unstable Media was established in Rotterdam, Netherlands. It is a centre established to promote the creation of media art, and collaborations among artists, scientists, software developers, technologists and theorists. They are best known for producing the Dutch Electronic Art Festival (DEAF), which was started in 1987.

\section{ZKM Center for Art and Media}

The ZKM Center for Art and Media in Karlsruhe, Germany was formed in 1989 to explore new media art and the impact it is having on contemporary art. It is a cultural institution that is composed of a Media Museum, Museum of Contemporary Art, the Visual Media and Music and Acoustics Institutes, which are engaged in research and production and a media centre, laboratory, as well as several events spaces. Over 500 international guest artists have produced works, which are part of the ZKM Collection. ZKM has one of the largest collections of media art extending back to the beginning of video art, electronic installation and holography. Their Media Library archive contains 1,200 art videos and 13,800 audio tracks.

\section{ISEA International}

The ISEA network was founded in 1990 in the Netherlands, and was originally called the InterSociety for the Electronic Arts. Their mission is to host an annual conference in locations such as Singapore, Hong Kong, Japan, Colombia and South Africa. The intent is to reach a global audience and bring together like-minded individuals. Their series of symposia was initiated in 1988 in order to support the founding and maintenance of an international network of organisations and individuals active in the field of the electronic arts. ISEA differs in several ways from other digital art organisations. While Ars Electronica and ZKM have specific locations and facilities, ISEA takes a more nomadic approach in line with its mission. It is also undergoing a significant expansion and gaining more attention from the digital art community in recent years.

\section{New York Digital Salon}

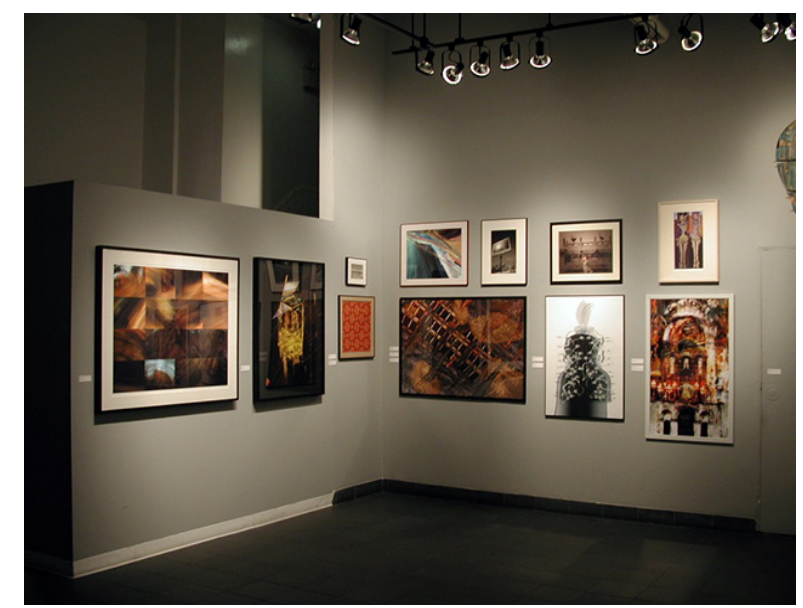

Figure 3: $9^{\text {th }}$ New York Digital Salon exhibition, Visual Arts Museum, New York City, 2002, photograph by Bruce Wands.

Established in 1993 to provide an annual venue for digital art in New York City, the salon continues to be an advocate for using digital tools and technology to create art. Originally planned as a one-time event, the success of the first exhibition 
prompted a ten-year run of large-scale exhibitions in New York City and venues in the Canary Islands, China, Italy, Korea, Portugal and Spain.

For the third through the tenth exhibitions, it partnered with Leonardo, Journal of the International Society for the Arts, Sciences and Technology, to create a catalogue of the exhibition and expand the amount of scholarly writing about digital art. The next major milestone in the salon's history was the tenth anniversary in 2003. They approached the National Endowment for the Arts, the New York State Council on the Arts and the Rockefeller Foundation and received grant support. The NEA and NYSCA grants helped to support the exhibition and the Rockefeller Foundation supported a Digital Art and Culture Symposium, which was held at the Museum of Modern Art Gramercy Theater in New York City. The symposium was held over two days with a variety of artists and curators participating. It was videotaped and this content is now on the www.nydigitalsalon.org website.

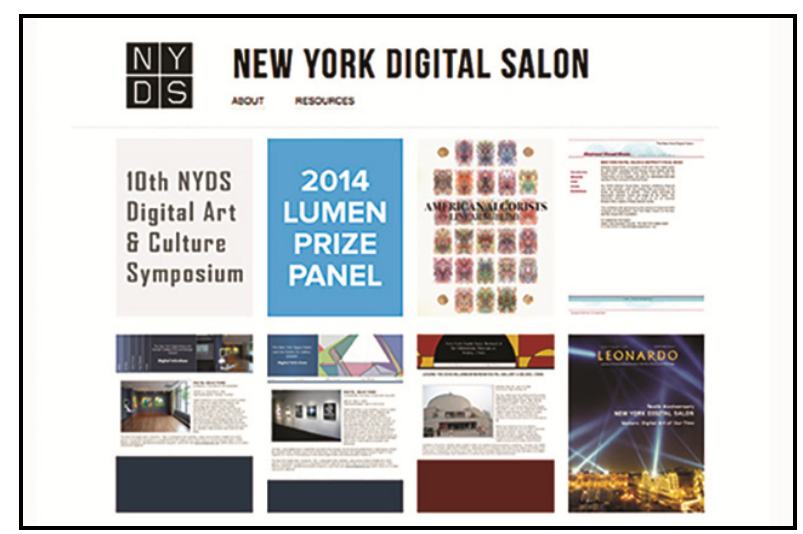

Figure 4: Screen grab of the

New York Digital Salon website.

The exhibition Vectors-Digital Art of Our Time was held at the World Financial Center in downtown New York City with a selection of artists. From that point on, it adapted a flexible curatorial practice to select artists from the Leonardo catalogues to accommodate different sized venues and to cooperate with smaller venues and local curators. To celebrate the twentieth anniversary of the New York Digital Salon, the exhibition The American Algorists: Linear Sublime, which showcases the works of Jean-Pierre Hébert, Manfred Mohr, Roman Verostko, and Mark Wilson and was presented and curated by $\mathrm{Dr}$ Grant Taylor, art history professor at Lebanon Valley College and author of When the Machine Made Art: The Troubled History of Computer Art. Jean-Pierre Hébert, Manfred Mohr, and Roman Verostko have also been given the Distinguished Artist Award for Lifetime Achievement in Digital Art by SIGGRAPH.

\section{Lumen Prize}

The Lumen Prize began in 2011 to celebrate art created digitally by artists from around the world. It does so through a website, annual competition and global tour. Based in Wales, UK, Lumen begins each annual cycle with an Awards Ceremony in London and then travels internationally. Exhibitions and talks have taken place in New York, Shanghai, Athens, Amsterdam, Riga, and Cardiff. Lumen has an international jury and an interesting model for curating its exhibition. The first phase is to publish a long list of selected works from all the entries, then the jury chooses a short list and the award winners. A People's Choice Award is also selected by visitors to the website. For the exhibitions, various venues have the option to design their exhibition from the chosen works. The Lumen Prize also functions to define new directions in digital art. There are various categories and in 2016, VR artworks became more represented, whereas VR art was not that prevalent even a few years ago.

As can be seen from the above, each digital art organisation has a unique focus and goals. As a group, they are interested in supporting new media and contemporary art. Some are focused on artists and exhibitions, while others incorporate research and have well developed facilities. Their involvement with digital art has been a critical component to the development of this art form and also a complement to the traditional art establishment's incorporation of digital art into contemporary art. The borders established during the 1960s through the 1990s are beginning to dissolve and being viewed differently, as those interested in the history of contemporary art now have access to extensive online archives of digital art, which were not easily accessible until the 1990s.

\section{CONCLUSION}

With these organisations in mind and now looking at them in context with digital art history and contemporary art, one can see that that there was a parallel history that co-existed. A large part of the initial resistance to digital art was due to the technological nature of it and the use of digital tools to make art. The rapid advances in technology made archiving this work difficult and much of the early work has been lost. Presently, new advances in technology have actually made the archives easy to access and expanded the digital tool set that artists can add to their creative practice.

As digital art continues to merge with contemporary art, the division between the two will continue to lessen. However, what is important is to rectify the art historical record to give digital art the rightful 
place it has earned in the contemporary art landscape. It is hoped that this paper helped to put digital art in context with contemporary art and to provide a guide to resources for those who want to learn more about it.

\section{RESOURCES}

Archive of Digital Art

https://www.digitalartarchive.at/database/databaseinfo/archive.html

Ars Electronica Archive

http://www.aec.at/about/archiv/

Digital Art Museum, Berlin, Germany

http://dam.org/home

ISEA International

http://www.isea-web.org
Leonardo Online Archive 1968-2017

https://muse.jhu.edu/journal/116

\section{Lumen Prize}

http://www.lumenprize.com/online-gallery

New York Digital Salon

www.nydigitalsalon.org

SIGGRAPH Digital Arts Community http://siggrapharts.ning.com

V2_ Center for the Unstable Media http://v2.nl

Victoria \& Albert Museum

http://www.vam.ac.uk/content/journals/researchjournal/issue-02/computer-art-at-the-v-and-a/

ZKM Center for Art and Media

http://on1.zkm.de/zkm/werke/ 